there would be a second pair of ships, also nine miles apart, also on a 227-047 bearing from each other, and also within the beam of this transmission; and in order to prevent the two ships which are concerned from talking at the same time, one might have a convention that the more northerly, or westerly, of the two will speak on the even minutes of G.M.T. and the other on the odd ones. At first contact, the bearing would usually be changing pretty slowly; the distance would not have to be very precise if the bearing was nearly right; and the nearest minute should be quite near enough for identification. It would still be possible that one was spoken to by two ships at once, and even more possible that one could hear two ships at once, without being addressed by both; however, moderation all round would keep these cases down, and one might also consider making one's receiver directional if necessary. A further possibility would be to have a (directed) 'asking' signal, combined with a directional receiver, and to have a rule that if traffic was heavy one would not speak unless asked to do so.

It would seem possible, by such means, to be told quite reliably what a ship was doing, many minutes before plotting could give any useful information; thus any ship which fitted and used such gear might have a reasonable hope that other ships would be glad to take the necessary steps to avoid her at a very early stage, while she kept on her course. If she did prefer to take action herself, there would be much less need to take extremely pronounced action, if she announced the change directly.

\title{
Early Pole Star Tables
}

\section{from Lieutenant-Commander D. W. Waters, R.N.}

I CAN N OT subscribe to Dr. Freiesleben's thesis that until the French Revolution induced a change of mind there was a big gap between men of science and seamen. ${ }^{1}$ It may be, as he states, that 'in the eighteenth century there was still a remarkable gap between scientific doctrine and practice' and it would be interesting to know the causes if this were so, but in the sixteenth and early seventeenth centuries there was, particularly in England, a quite remarkable and organized liaison between scientists and seamen with the specific purpose of improving the art of navigation. The object, as Thomas Digges expressed it in 1579, was 'to reduce Imaginative Contemplations to Practical Conclusions'; in other words, it was to make scientific discoveries and inventions to improve the accuracy of navigation. ${ }^{2} \mathrm{~A}$ few examples must suffice in the space available to support this statement.

Dr. Freiesleben notes "that Nonius and the German cosmographers give the distance of Polaris from the Pole as $4^{\circ} 9^{\prime}$, whereas the contemporary seamen knew the correct value to be $3 \frac{1}{2}^{\circ}$ ', and cites this as illustrating 'the estrangement between scientific doctrines and practical experience' at sea in the sixteenth century. The reverse is, in fact, the case. In 1545 Martin Cortes completed his Breve Compendio de la sphera y de la arte de navegar (Seville, 1551) and specifically included Johann Werner's polar distance of $4^{\circ} 9^{\prime}$ in preference to the $3^{\circ} 30^{\prime}$ in current use by seamen as he supposed it to be more accurate. 
Cortes claimed his book to be the first Spanish navigation manual. In fact, Pedro de Medina's Regimiēto de Navegaciō (Seville, I 543) and Arte de Navegar (Seville, 1 545) were the first in print. If we discount Martin Fernandez de Enciso's translation, Suma de Geographia (Seville, 1518), of the Portuguese MS. manual Regimento de Navegacion written by Andreas Pires, 3 Cortes' and Medina's manuals were the first Spanish ones; and Cortes' unlike Medina's was right up to date with the latest scientific theories on terrestrial magnetism and the phenomenon of variation and with the latest table of polar distances. While it was Medina's Arte de Navegar which was most popular with continental seamen it was, wisely, Cortes' work which was selected for translation and publication as the first English manual of navigation, The Arte of Navigation (London, 1561), translated by Richard Eden on the advice of Stephen Borough.

It was unfortunate that Cortes' erroneous polar distance was incorporated, in all good scientific faith, in the English translation. One consequence was an inability on the part of many navigators to reconcile their observed noon position with their observed morning and evening twilight positions using the Pole Star. The cause was pointed out by Edward Wright in his Certaine Errors in Navigation (London, I 599). Subsequent Pole Star tables were amended, while Edward Wright's book found immediate acceptance amongst seamen. His work was a classic example of 'the furtherance of [navigational] skill' as a result of 'practisers in that Arte, and such as are Students of the Mathematikes' conferring together-to use William Barlow's words in The Novigator's Supply (London, $1597)$.

Pedro Nuñez' explanation of the spiral nature of rhumb-lines (1537) won prompt acceptance at sea. By 154I, Mercator had produced a terrestrial globe incorporating these rhumb-lines and also Nuñez's flexible quarta altitudino, which device, together with the rhumb-lines made his globe of the greatest practical value to seamen. A dozen years later Dr. John Dee devised his paradoxall compass, or circumpolar chart, for the use of the Muscovy Company's navigators. This projection has continued in use until today. In 1594 the Molyneux globes were published in London, the largest globes made so far for navigational use, and made large to render them of greater navigational use.

Competent navigators were well aware in the sixteenth century of the faults of the plain chart but used the chart (and globes) for lack of a better. Mercator's world chart of 1569 was on too small a scale to be of practical value. Sir Walter Raleigh employed the mathematician Thomas Hariot to teach his sea captains navigation and Hariot discovered the mathematical formula for Mercator's projection in the late 1580 's or early 1590 's. Concurrently the mathematician Edward Wright, employed by the Earl of Cumberland, made the same discovery (1 $5^{89}$ ). His published description of 1599 -it was first briefly described and illustrated by Blundeville in his Exercises (London, 1594)-was immediately followed by the production and use at sea of ocean and other charts on this projection.

Gemma Frisius had propounded finding longitude by difference of time (chronometer) in 1522 and this solution found prompt acceptance amongst seamen as the correct one. Watches were improved and by 1561 the French and by ${ }_{1}{ }_{1} 82$ the English, were attempting to use this method. Twenty years later, the East India Company's first expedition was equipped with watches for the purpose. Indeed, from the sixteenth century, the development of watches and chronometers was almost entirely in response to the expressed needs of seamen 
-the only men before the railway age to whom the accurate measurement of time was a matter of life or death. The Royal Observatory at Greenwich was, of course, founded in the seventeenth century specifically for the purpose of 'perfecting the art of navigation'. In the meantime, seamen perforce checked their longitude by celestial observations (Baffin, 1615, James, 1630) conscious when they did so of the wide range of error the observations were susceptible to on account of the limitations of the instruments and astronomical tables available. These methods were rarely used because it was a waste of time to practical seamen unless on exploration bent. They were not used before the seventeenth century because the necessary tables of trigonometrical functions had not been published in a suitable format.

Instruments for finding variation were devised by the Portuguese in the 1530 's. In the I 580 's improved instruments were developed in England (William Borough, The Variation of the Cumpas, London, 1581) and were widely used at sea, in conjunction with Portuguese and Dutch tables for finding (longitude) position (Richard Hakluyt's Principal Navigations, London, I 598-I600, and Edward Wright's Haven-finding Art, London, 1599). Robert Norman's discovery of dip (The Newe Attractive, London, 1581 ) was quickly exploited by the manufacture of improved dip rings (William Gilbert, De Magnete, London, 1 599) and the publication of tables of dip, compiled by three mathematicians for position (latitude) finding at sea when celestial observations were impracticable (Thomas Blundeville, The Theoriques of the seven Planets, London, 1602).

These are typical examples of the close cooperation of seamen and scientists in Elizabethan days to improve navigational practice. That none of these methods of position-finding was found practical should not obscure the fact that the seamen were in fact making prompt use of the latest scientific discoveries and inventions. Nor did this cooperation cease. Telescopes developed commercially by the Dutch in 1609 were at sea within a very few years. Galileo's discovery of four of Jupiter's satellites ( 1610 ) was followed only six years later by his tables and 'observation helmet' for finding longitude at sea by observation of the satellites. Seamen rejected the method only because it proved unpractical.

In the I 550's Richard Chancellor devised the diagonal scale for use in nautical instruments (Thomas Digges, Alae, Seu Scalae, London, 1573). In conjunction with astrolabes of larger diameter an immediate improvement in the accuracy of celestial observations was possible. In the 1580 's Thomas Hood invented a cross-staff incorporating the principle of observing the shadow cast by the Sun (The Use of the two Mathematicall instruments, London, 1590). So too, did Captain John Davis who within a decade had perfected the vastly superior back-staff or Davis quadrant. It won immediate acceptance at sea because of its unprecedented accuracy. In the 1670's Flamsteed incorporated a lens in the shadow vane. ${ }^{4}$ This focused the Sun's rays on to the horizon vane and made observation on dull days feasible and further increased the accuracy of observation. Its use at sea was being taught in the 1680's, and instruments so fitted were used at sea.

Wright's publication in 1599 of the formula for Mercator's projection opened the way towards an entirely new system of navigation. Englishmen had been striving towards it for the preceding twenty-five years (Thomas Digges, $A$ Prognostication everlastinge, London, 1576; John Davis, The Seamans Secrets, London, 1595). That navigational practice was in fact revolutionized in the succeeding twenty-five years was entirely due to the planned application of mathematical discoveries and inventions to the improvement of the navigator's 
art. In this revolution there were two main organizations involved, first and foremost Gresham College, opened in London in 1598, and the East India Company, chartered in London in 1600 . Two of the Gresham professors were to teach publicly mathematics and astronomy and in doing so were 'to explain the use of common instruments for the capacity of mariners', and were to apply 'these things' to use by reading geography and the art of navigation. Instruction was to be in English, and it was to be tuned to 'the pitch and capacity' of the audience. The result of these far-sighted provisions was what the merchant founder of the college had planned-a revolution, a scientific revolution, in the practice of navigation at sea. Charts, chart-work, methods and means of calculation, nautical tables, mathematical instruments, compasses, logs, log-bookseverything navigational was affected and markedly improved.

The mathematician Thomas Hood had invented a Sector in 1597 for the rapid solution of trigonometrical problems (The Making and Use of a Sector, London, 1597). Ten years later, the mathematician. Edmund Gunter improved it specifcally for facilitating the solution of navigational problems on Mercator charts. It came into popular demand at once, the description being printed some seventeen years later (De Sector et Radio, London, 1623). Raphe Handson (Trigonometrie, London, 1614) and John Tapp (R. Norman, The Newe Attractive, London, I614), both mathematicians, published the trigonometrical formulae for the solution of navigational problems in conjunction with the use of Mercator charts, trigonometrical tables and the Sector. Of these formulae the mid-latitude formula, which incidentally sounded the death knell of the globe at sea, was of the greatest importance. Tables of the natural trigonometrical functions suitable for use with the formulae were published from 1594 onwards in various works. Traverse tables were progressively developed by Wright (1 599 and 1610) and Gunter (1623) for use with the Mercator charts. In 16 44 Napier published his logarithms (Mirifici Logarith morum Canonis descriptio, Edinburgh, 1614). Edward Wright, with the later assistance of the mathematician Henry Brigges, immediately undertook their translation into English for the specific use of the East India Company's navigators (A Description of the Admirable Table of Logarithms, London, 1616). Gunter and Brigges computed and published logarithms to base io for round numbers (H. Brigges, Logarithmorum Chilias Prima London, I617) and for trigonometrical functions (E. Gunter, Canon of Triangles, London, 1620), and both taught their use in navigation at Gresham College. Gunter also introduced the knotted log-line and the so-called Dutchman's Log (1623) and amended the length of a degree and the nautical mile. Concurrently he invented the scale called after his name for the logarithmic solution of navigational problems by means of an instrument (in effect Gunter's Scale was a slide rule) which came into immediate use at sea. John Aspley published his description of a plain scale in 1624 for the instrumental solution of problems on plain and Mercator charts. This again was highly popular at sea (J. Aspley. Speculum Nauticum, London, 1624).

Since the turn of the century seamen had known about and had had tables for correcting dip, parallax and refraction. That they did not often use them was because, as Wright pointed out (1599), their means of observation were not sufficiently accurate to justify applying the corrections.

From 1602, when John Tapp first published his Seamans Kalendar in London, navigators had a regularly published Nautical Almanac, many were thoroughly conversant with the means of finding longitude at sea, and with great-circle 
sailing-described in print first by Richard Norwood (Trigonometrie, London, 1630), who introduced the progressively knotted log-line in 1637 (The Seamans Practice, London, 1637), and a still more accurate measurement of the nautical mile, and improved traverse tables.

Certain facts are irrefutable. In the early seventeenth century the English established a lucrative trade with the Indies in the East and flourishing colonies in North America and the Caribbean. They were able to do so only because of their skill in navigation. By the middle of the seventeenth century the English were carrying on a substantial oceanic trade. They were also involved in wars at sea. Their skill in navigation was sufficient for neither their trade nor their naval operations to suffer through the difficulty of sailing ships successfully to desired landfalls. The instruments, charts and tables available to them were of an unprecedented accuracy and the means of mathematical calculation of an unprecedented simplicity, yet capable of an unprecedented exactitude. Every development had been the direct result of the conscious and prompt application of scientific discoveries and inventions to the art of navigation. John Tapp wrote in his Seamans Kalendar (London, 1602) - the first regularly published Nautical Almanac - as the Mathematicall Sciences are the grounds of Navigation, so is Navigation the only meanes, whereby the excellency of those Artes and Sciences are proved and layde open to the view of the world'. And that was true, substantially, until 'after I 800 , when our technical age began' on shore.

As early as $158 \mathrm{r}$ Robert Norman in The Newe Attractive had defined the scientific method that governed successful navigation in his day and that led to its rapid and revolutionary improvement in the next half century. 'I have,' he wrote, 'set doune whatever I could finde by exact triall, and perfect experiments ... foundyng my argumentes onely upon experience, reason and demonstration, which are the groundes of Artes'. The men of that age, it is true, 'are passed away', in the words of the psalmist, 'like a shadow, and as a ship that passeth over the waves of the water, which when it is gone by the trace of thereof cannot be found, neither the pathway of the keel in the waves', but the printed page, the hand-drawn chart, the cunning instruments of wood and bone and brass that they contrived remain as memorials. Let not, therefore, 'iniquitie of tyme bury in oblivion so woorthy attemptes, so much the greatlyer to bee esteemed as before neuer enterprysed by Englysshemen',5 for as Purchas truly observed in His Pilgrimage (London, 1614) the Elizabethan and early Stuart navigators practised 'the art of arts, navigation' on a scientific basis.

\section{Professor E. G. R. Taylor comments:}

Commander Waters surely exaggerates the degree of cooperation between sailor and scientist prior to the nineteenth century. Familiar as he is with Elizabethan sea-books he must recall the rude remarks of the mathematician Thomas Digges about the former, and William Borough's snub to the latter, which Hakluyt printed. And there are endless complaints through the centuries both by French and English writers about the way that masters clung to outmoded and faulty practices. Captain Edward Harrison, with a temporary commission in the navy, had a fling at both sides. Carrying a new idea about the longitude to the Royal Society was 'like throwing pearls before swine', while having served in all rates of ships-from first to sixth-he had not set eyes on a single azimuth compass in one of them. He was writing in 1696 . Then there was Mr. Malachy Postlethwayt, who compiled the enormous Universal Dictionary of 
Trade and Commerce which ran through several editions. Writing about $175^{8}$ he noted that the 'judicious friends' of 'the ingenious Mr. Harrison . . . suspect that he will entirely perfect his most elaborate instrument'. But in his view seamen 'had very little concern about the perfecting of the discovery of the longitude'. And he quotes the famous John Robertson, author of The Elements of Navigation as saying that 'most of our mariners' belong to the class of readers who merely wish to learn the rules by rote, never troubling themselves about the reasons. It would be an exceptional sailor who questioned what he read in his manual, and the figure of $3 \frac{1}{2}^{\circ}$ for the distance of Polaris from the pole was certainly no longer correct when Cortes wrote in 1551 . It derived, not from seamen, but from the Portuguese astronomers of 1480 or thereabouts, and had been diminished by precession. But who besides an astronomer could dream of that?

\section{REFEREN CES}

1 Freiesleben, H. C. (1955). Early pole star tables. This Journal (Forum), 8, 285.

2 Digges, T. An Arithmeticall Militare Treatise called Stratioticos (London, 1579).

3 Taylor, E. G. R. (Ed.) (1932). A Brief Summe of Geographie, Hakluyt Society, Second Series, 69, XV, London.

4 Perkins, P. The Seamans Tutor, London, 1682.

$s$ Eden, R. 'The Description of the Two Viages into Guinea', in The Decades of the New Worlde, London, 1555.

\section{THE THURLOW AWARD}

THE American Institute of Navigation announces the award to Mr. Paul Duane Schrock of the Thurlow Award, for his contributions to navigation in the development of airborne automatic dead reckoning equipment. The Thurlow Award is offered annually by the American Institute for what is deemed to have contributed most to the science of navigation during the year. Last year's recipient was Captain F. J. Wylie, R.N. 